\title{
Actions Brought Against Delegated Commission Regulation 2020/217 Concerning Classification of Titanium Dioxide
}

\author{
Tobias Schulz*
}

\section{Introduction}

Titanium dioxide $\left(\mathrm{TiO}_{2}\right)$ is the most produced and used pigment worldwide and subject of an ongoing debate about its safety. In 2016, France filed a proposal to classify $\mathrm{TiO}_{2}$ carcinogenic to humans when inhaled (cat. 1B). ${ }^{1}$ In its corresponding opinion, ECHA's Risk Assessment Committee (RAC) did not follow the French proposal but suggested a classification of $\mathrm{TiO}_{2}$ as suspected of causing cancer (cat. 2) by inhalation. ${ }^{2}$ In October 2019, the EC announced the all in all highly controversial ${ }^{3}$ classification of $\mathrm{TiO}_{2}$ within the 14th ATP of CLP-Regulation $1278 / 2008$ by Delegated Commission Regulation $2020 / 217^{4}$, limiting, however, the cat. 2-classification to the $\mathrm{TiO}_{2}$ powder form containing $1 \%$ or more of particles with aerodynamic diameter $\leq 10 \mu \mathrm{m}$ (Article 1, No. 3, Annex III). Hence, $\mathrm{TiO}_{2}$ powder classified as suspected of causing cancer will need to be treated as hazardous substance/mixture. Accordingly, a safety data sheet must be available and the powder be notified to the poison notification centre (Article 45 CLP).

Furthermore, regulation 2020/217 constitutes a labelling obligation for liquid and solid mixtures containing $\mathrm{TiO}_{2}$ (Article 1, No. 1, Annex I):

- The label on the packaging of liquid mixtures containing $1 \%$ or more of titanium dioxide particles with aerodynamic diameter equal to or below 10 $\mu \mathrm{m}$ shall bear the following statement:

DOI: $10.21552 / \mathrm{icrl} / 2020 / 2 / 9$

* Tobias Shulz is an Advisor at German Chemical Industry Association (Northeast Germany Branch). For Correspondence: $<$ To bias.Schulz@lv-no.vci.de>

1 CLH report for Titanium dioxide, May 2016, version 2.

2 RAC, Opinion on Titanium dioxide, 14 September 2017, p. 40.

3 See Annex 2 of the $\mathrm{CLH}$ report which provides hundreds of pages of objections raised by numerous states and organisations. During the public consultation, 514 comments (!) were received.

4 OJ 2020 L 44, p. 1.

5 Corrigendum to Commission Delegated Regulation (EU) 2020/217 of 4 October 2019, OJ 2020 L 51, p. 13.

6 CWS Powder Coatings/Commission, OJ 2020 C 222, p. 35, and Brillux and DAW/Commission, OJ 2020 C 222, p. 39.
- EUH211: 'Warning! Hazardous respirable droplets may be formed when sprayed. Do not breathe spray or mist.'

- The label on the packaging of solid mixtures containing $1 \%$ or more of titanium dioxide shall bear the following statement:

- EUH212: 'Warning! Hazardous respirable dust may be formed when used. Do not breathe dust.

The regulation entered into force March 2020. The new classifications and the labelling obligations will apply from 1 October 2021. Substances and mixtures may that date be classified, labelled and packaged accordingly (Article 3 and Corrigendum ${ }^{5}$ ).

\section{Actions}

In May 2020, several colour manufacturers have brought actions against the Delegated Commission Regulation 2020/217 (Cases T-279/20 and T-288/20). ${ }^{6}$ The applicants claims that the Court should annul Commission Delegated Regulation (EU) 2020/217 in so far as it concerns the classification and labelling of titanium dioxide. Among other things, the applicants argue that:

- the EC infringed Article 53C CLP by adopting a single act for different matters,

- the classification of $\mathrm{TiO}_{2}$ carried out in the contested regulation does not comply with the classification requirements pursuant to Article 53a, Article 37(5) and Article 3(1) CLP, read in conjunction with point 3.6.2.2 of Annex I,

- that the amendment to Annex II CLP as regards liquid and solid mixtures with a titanium dioxide component cannot be made on the basis of Article 53(1) CLP, read in conjunction with Article 53a,

- that the EC infringed its obligation to carry out an impact assessment prior to the adoption of the contested regulation,

- that the contested regulation infringes the principle of proportionality, since the classification of certain titanium dioxide particles and the laying down of labelling obligations is not appropriate 
for the purpose of attaining the objective (health protection) and there are less onerous means available.

The actions mark the final stage of a long lasting and, partially, emotional dispute about the safety of $\mathrm{TiO}_{2}$. It is rather unlikely that the General Court will decide within the transition period which ends 30 September 2021. 